\title{
Urgences
}

\section{Joualerie de joualgie}

\section{Denis Belzile}

Numéro 15, octobre 1986

Épigraphiques

URI : https://id.erudit.org/iderudit/025322ar

DOI : https://doi.org/10.7202/025322ar

Aller au sommaire du numéro

Éditeur(s)

Urgences

ISSN

0226-9554 (imprimé)

1927-3924 (numérique)

Découvrir la revue

Citer ce document

Belzile, D. (1986). Joualerie de joualgie. Urgences, (15), 57-57.

https://doi.org/10.7202/025322ar

Ce document est protégé par la loi sur le droit d'auteur. L’utilisation des services d'Érudit (y compris la reproduction) est assujettie à sa politique d'utilisation que vous pouvez consulter en ligne.

https://apropos.erudit.org/fr/usagers/politique-dutilisation/
Cet article est diffusé et préservé par Érudit.

Érudit est un consortium interuniversitaire sans but lucratif composé de l’Université de Montréal, l'Université Laval et l'Université du Québec à Montréal. Il a pour mission la promotion et la valorisation de la recherche. https://www.erudit.org/fr/ 


\section{Denis Belzile \\ JOUALERIE DE JOUALGIE}

Chérie ch't’aim' pluss' que mon cheval

Pour un K-boy c'est pas normal

Willie Lamothe: chanson western

C'tait le premier juillet d'l'année passée

J'm'en rappelle avec nostalgie

Comme d'ma première turque des Maple Leafs

Le ciel pétillait comme du crème soda

Pis moé j'me sentais grand comme King Kong

On s'tenait collés comme une gaufre moé pis ma blonde

Deboutte on s'tait installés dans des tires

C'qui nous faisait une belle habit

Pis là ben!... on s'envoyait en l'air comme des câliques

La lune débordait la nuit

Pis moé j'me voyais léger comme un hors-corps

Mé tout à coup qu'on n'ortombe pus là!

M'avait dit ma blonde à travers les chants d'crapottes

Maudit qu'on 'vait ri là-d'ssus

Pis là on a eu chaud près d'la p'tite école

Pis on a enlevé un tire (un tire d'été)

Les étouèles flyaient comme des machines à boules

Pis moé j'frétillais à force flipper

On 'tait partis ensemble c'ta fois-là

J'm'imaginais éjaculer des p'tites pleines lunes

99 millions de p'tites pleines lunes

Et qui faisaient de ma blonde une galaxie qu'elle était déjà

Le vent goûtait bon comme un french

Pis moé pis ma blonde on sé laissé fondre comme un peu d'neige 